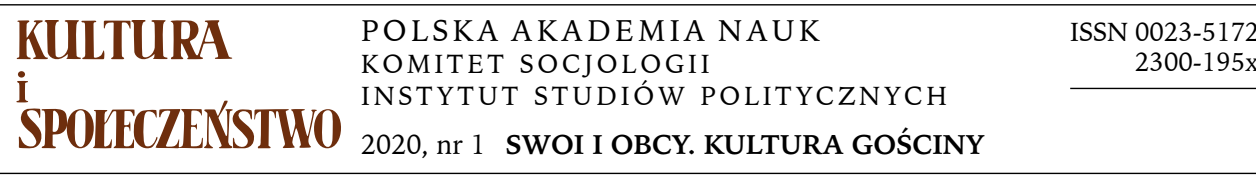
$\begin{array}{llllllll}A & R & T & Y & K & U & 亡 & Y\end{array}$
I
$\begin{array}{llllllll}\mathbf{R} & \mathbf{O} & \mathrm{Z} & \mathbf{P} & \mathbf{R} & \mathrm{A} & \mathrm{W} & \mathbf{Y}\end{array}$

ADAM PISAREK

Uniwersytet Śląki w Katowicach

\title{
ŻYWE STREFY WYOBRAŹNI. PRZYJMOWANIE GOŚCI JAKO PRAKTYKA OPORU?
}

\section{WPROWADZENIE: PRZEMOC BIUROKRACJI}

David Graeber - amerykański antropolog i znany aktywista kojarzony z anarchizmem (Graeber 2002) - w 2006 roku na zaproszenie London School of Economics wygłosił wykład w ramach prestiżowego cyklu „Malinowski Lectures”. Tytuł wystąpienia brzmiał Beyond Power/Knowledge: An Exploration of the Relation of Power, Ignorance and Stupidity ${ }^{1}$. Z czasem powstawały kolejne, papierowe i elektroniczne wersje jego przemowy, opublikowane jako esej Dead Zones of the Imagination: On Violence, Bureaucracy, and Interpretive Labor w „HAU. Journal of Ethnographic Theory” (Graeber 2012) oraz jako Martwe strefy wyobraźni w przetłumaczonej na język polski książce Utopia regulaminów (Graeber 2016).

Graeber przedstawia w swoim tekście stanowisko polemiczne wobec Foucaultowskich koncepcji biowładzy i rządomyślności (Foucault 2010). Przekonuje, że skupianie się na badaniu rozproszonych technik władzy wpływających na życie społeczne sprawia, iż mniej widoczna staje się fizyczna przemoc leżąca u podstaw wielu form nierówności między ludź-

Adres do korespondencji: adam.pisarek@us.edu.pl; ORCID: 0000-0002-9872-364X

${ }^{1}$ Zobr. archiwum nagrań wykładów w LSE (https://digital.library.lse.ac.uk/objects/lse: viz386gos [dostęp: 12.09.2019]). 
mi. Form, w których władza obywa się bez wiedzy, gdyż groźba użycia siły wystarcza, by utrzymać niesprawiedliwe hierarchie. Za tymi twierdzeniami Graebera kryje się zdecydowana krytyka współczesnego porządku biurokratycznego i niezgoda na traktowanie go jako dobrze działającego mechanizmu. Tłumaczy on, że narzędzia wykorzystywane przez aparat państwowy nie przystają do rzeczywistości, w której są stosowane, a wprowadzanie ich siłą tłamsi ludzką zdolność do rozszyfrowywania sensów rządzących światem społecznym. Tam, gdzie Foucault widzi zinternalizowane formy dyscyplinujące ciała i umysły jednostek z jednej strony, a populacje z drugiej, Graeber dostrzega przede wszystkim niezgrabność aparatu państwowego. Biurokracja w tym kontekście stanowi dla niego maszynę służącą produkowaniu i podtrzymywaniu poczucia alienacji, a nie jedną z technik kształtujących samokontrolujące się podmioty.

Jak i dlaczego tak się dzieje? Według Graebera stosowanie biurokratycznych procedur tworzy obszary życia „tak wyzute z wszelkiego potencjału głębi interpretacyjnej, że odpierają każdą próbę przypisania im wartości czy sensu" (Graeber 2016, s. 131). Wdzierają się także w strefy dotąd stymulujące ćwiczenia z wyobraźni społecznej, by zmienić je w martwe pola zdominowane przez aparat władzy. Graeber podaje przykład rytuałów pogrzebowych, które nie mogą się dziś odbyć bez aktu wypełniania dziesiątek podobnych do siebie formularzy. Zaznacza, że wiele kultur $\mathrm{w}$ różnych czasach opracowywało bardzo złożone formalnie i treściowo systemy żegnania zmarłego, czyli akty przebudowywania i wygaszania relacji społecznych po śmierci osoby. Do dzisiaj są to systemy żywe, ale równorzędną, jeśli nie fundamentalną moc sprawczą zyskały proste zapisy na kartkach papieru - konieczne z punktu widzenia aparatu administracyjnego. Graeber zauważa jednak, że w dokumentach, które należy wypełnić po czyimś zgonie, nie ma żadnej symboliki czy też wartości, brakuje w nich ukrytych sensów - są dokładnie tym, co jest na nich napisane (Graeber 2016, s. 69). Tak działają forpoczty biurokratycznego porządku wnikającego w sfery tradycyjnego kształtowania się wyobraźni społecznej. Czasami tylko modyfikują dotychczasowe struktury, czasami całkowicie je zastępują. Za każdym razem ograniczają jednak ujętą w kulturowe konwencje pracę interpretacyjną ${ }^{2}$.

\footnotetext{
${ }^{2}$ Graeber używa formuły interpretative labor, która została przetłumaczona na język polski jako „praca interpretacyjna”, co nie uwzględnia wszystkich konotacji słowa labor, przywołującego na myśl także siłę roboczą i robociznę z jednej strony, a trud i wysiłek z drugiej (Graeber 2012, s. 116). Dziękuję Recenzentowi za cenne wskazówki, uważną lekturę artykułu i za zwrócenie uwagi na ten i inne problemy związane z zastosowaniem koncepcji pracy interpretacyjnej do analizy zjawiska gościnności.
} 
Ta zaś w koncepcji Graebera jest kluczowa. Moglibyśmy ją opisać jako część codziennego życia społecznego, która polega „na próbach odszyfrowania, co czują i czym kierują się inni ludzie" (Graeber 2016, s. 88). Graeber określa ją także jako wszelkie starania przeniknięcia motywacji ludzkich, zamiarów i wartości kierujących postępowaniem innych. Związane $z$ nią kompetencje i wyobrażenia uznaje przy tym za istotną formę wiedzy, a wzorzec „współodczuwającej identyfikacji” za jeden $z$ ważnych mechanizmów rządzących życiem społecznym ${ }^{3}$. Następnie, podążając za teorią punktu widzenia bell hooks, zauważa, że w strukturach opartych na przemocy, zwykle to osoby znajdujące się nisko w hierarchii muszą wykonywać omawiany typ pracy ${ }^{4}$. Tworzy to sytuację, w której utrwalają się „asymetryczne struktury wyobraźni”. Biurokracja, mając oparcie w aparacie przemocy, jest formą zarządzania owymi nierównościami, a często także sposobem na zatrzymywanie pracy interpretacyjnej w ogóle ${ }^{5}$.

Tutaj nie chcę jednak skupiać się na biurokratyzacji i rozprzestrzenianiu się martwoty, lecz na historycznie trwałym wzorcu aksjonormatywnym wspierającym pracę interpretacyjną. Mam zamiar przyjrzeć się tym jego aspektom, które umożliwiają kształtowanie się rozmaitych form oporu wobec procesu opisanego wyżej, łatwego do prześledzenia także w kulturze polskiej. Przede wszystkim będzie mnie interesować, w jaki sposób prezentowany wzorzec tworzy warunki możliwości powstawania obszarów, które nazywam tu żywymi strefami wyobraźni. Jednocześnie pragnę zaznaczyć, że uznaję gościnność za wzór idealny, który może wpływać na konkretne wyobrażenia kulturowe, wzory zachowań i praktyki kulturowe, ale nie jest z nimi tożsamy i nie oferuje gotowych scenariuszy działania.

\footnotetext{
${ }^{3}$ Potwierdzają te intuicje chociażby badania prowadzone pod szyldem teorii umysłu przez takich badaczy jak Michael Tomasello (2015).

${ }^{4}$ Badania roli czarnych służących w domach białych w Stanach Zjednoczonych Ameryki dają wgląd we wzorcowy przykład działania tego mechanizmu (hooks 1992).

${ }^{5}$ Należy przy tym zauważyć, że Graeberowska krytyka Foucaultowskiej koncepcji władzy-wiedzy, polegająca na wskazaniu możliwości zaistnienia relacji władzy bez wiedzy, w dużej mierze wynika z przesunięcia dokonanego przez amerykańskiego antropologa w obrębie rozumienia tego, czym jest sama wiedza. Dla Foucaulta (1997, s. 221) savoir to wszystko, „o czym można mówić w danej praktyce dyskursywnej i dzięki czemu praktyka się wyodrębnia". Natomiast Graeber mówi przede wszystkim o wiedzy jako wyniku trafnego zrozumienia odmiennych punktów widzenia, co bliższe jest myśleniu o niej jako efekcie pracy empatii. Władza działająca bez wiedzy to dla Graebera przede wszystkim fizyczne formy przemocy, które ograniczają możliwość zrozumienia innych. To relacji między nimi a pracą interpretacyjną będę przyglądał się uważniej w dalszej części artykułu. Jednocześnie pragnę zaznaczyć, że zatrzymanie pracy interpretacyjnej niekoniecznie musi oznaczać zanikanie savoir, choć takie wnioski mogą wynikać z lektury argumentacji Graebera.
} 


\section{ŻYWA STREFA WYOBRAŹNI}

Graeber uznaje, że w kontrze do asymetrycznych, zreifikowanych i trudnych do naruszenia struktur pozostają momenty rewolucyjne, za którymi idzie eksplozja twórczości społecznej, artystycznej i intelektualnej. Dotychczasowe wzorce identyfikacji załamują się, „wszyscy eksperymentują, próbując zobaczyć świat z nieznanych sobie punktów widzenia" (Graeber 2016, s. 129). Ostatecznie mogą powstać wtedy nowe ramy, w których odbywa się dotąd tłumiona praca interpretacyjna.

Blisko tej myśli do Turnerowskiego opisu przebłysków communitas, dlatego warto w tym miejscu przypomnieć dwie klasyczne już uwagi angielskiego antropologa. Pierwsza dotyczy tego, że communitas stanowi „relacj[ę] pomiędzy konkretnymi, historycznymi, poszczególnymi jednostkami. Jednostki te nie są zaszeregowane do ról i statusów, ale stoją wobec siebie nawzajem raczej w formie opisanej przez Martina Bubera jako «Ja» i «Ty»" (Turner 2010, s. 143). Turner dodaje, że jest to „bezpośrednia, natychmiastowa i całkowita konfrontacja ludzkich tożsamości" w homogenicznej, nieustrukturyzowanej formie.

Druga uwaga związana jest $z$ procesem transformacji communitas egzystencjalnego (spontanicznego, często opartego na emocjach, krótkotrwałego) w communitas normatywne (ustabilizowane ze względu na to, że wytworzona została nowa struktura). Dla autora Gier spotecznych, pól i metafor ów proces jest nieuchronny, albowiem „wraz z upływem czasu narasta potrzeba mobilizacji i organizacji zasobów, a także potrzeba kontroli społecznej wśród członków grupy dążących do wspólnego celu" (Turner 2010, s. 144.). Tworzenie równościowych, pozbawionych asymetrii relacji często jest $\mathrm{w}$ tej perspektywie możliwe tylko krótkoterminowo. Jedynym sposobem na ustabilizowanie takiego stanu okazuje się zbudowanie wokół niego nowych hierarchii i struktur.

Z Turnerowskich teorii wyłania się więc obraz dynamicznej pętli, w której communitas i struktura są wzajemnie napędzającymi się siłami zapewniającymi dynamikę różnorodnych procesów społecznych. Graeber natomiast zwraca uwagę przede wszystkim na wyzwalającą moc wydarzeń przełamujących stabilne, hierarchiczne struktury - wydarzeń, które określa jako „festiwale oporu”. Zalicza do nich Occupy Wall Street (ruch, którego był jednym z ojców założycieli) oraz Arabską Wiosnę:

„Każda z tych inicjatyw była jednocześnie akcją bezpośrednią, rzuconym władzy w twarz aktem autentycznej demokracji, a także eksperymentem mającym pokazać, jak mógłby wyglądać porządek społeczny wolny od biurokracji, oparty na potencjale praktycznej wyobraźni” (Graeber 2016, s. 130). 
Jako bardziej aktualny przykład można podać „Marsze dla klimatu”, na których trwa intensywna praca wyobraźni już nie tylko dotycząca relacji między ludźmi, ale negocjująca także pozycje bytów innych klas.

Poza krótkimi momentami rewolucyjnymi istnieją jednak także stabilniejsze, ustrukturyzowane obszary życia społecznego, w których praca interpretacyjna trwa w najlepsze. Tak właśnie definiuję żywe strefy wyobraźni. Widzę je bowiem nie jako egzystencjalne communitas, lecz raczej zinstytucjonalizowe formy, które są tak głęboko zakorzenione w kulturze, a jednocześnie tak elastyczne, że umożliwiają powszechnie akceptowalne i nieburzące dotychczasowego porządku rzeczywistości społecznej ćwiczenia $z$ „widzenia świata oczami drugiego człowieka” (jak mówi Graeber) lub kształcenie kompetencji z zakresu „intencjonalności współdzielonej” i „kolektywnej” (jak powiedziałby Tomasello). Dlatego właśnie są gęste od znaczeń i wspólnych historii, stanowią bazę budowania porozumienia, uzgadniania sensów, tworzenia i utrwalania akceptowalnych punktów odniesienia dla rzeczywistości społecznej, integracji przekraczającej niektóre trwałe granice i hierarchie, a wzmacniającej inne. Turner (2010, s. 144) dodałby, że pozwalają na uproszczenie struktury społecznej, a jednocześnie łączą się z "rozrostem struktury ideologicznej w formie mitów i sacra”. Zaznaczyłby też pewnie, że łączą się ze stanami „liminoidalnymi”, czyli charakterystycznymi dla społeczeństw przemysłowych i poprzemysłowych z tego względu, że zostają „oderwane od bezpośrednich funkcjonalnych działań, jakie podejmują członkowie społeczeństwa" (Turner 2005, s. 12). Między innymi $z$ tego względu nie są związane $z$ formami nasilonego przymusu i ograniczeń narzucanych z zewnątrz. Często stanowią mniej lub bardziej niezobowiązujące formuły, co powoduje, że stają się łatwiejsze do przyswojenia, lecz jednocześnie trudniejsze do zbadania, gdyż różnorodność konwencji i realizacji z nimi związanych może być wielka.

Zdaję sobie sprawę, że nie każda sytuacja przyjmowania gości będzie wiodła $\mathrm{w}$ kierunku communitas, liminoidalności i utworzenia żywej strefy wyobraźni, dlatego moim celem będzie wyłącznie zbadanie, dlaczego odwoływanie się do wzoru idealnego gościnności może sprzyjać powstawaniu takich przestrzeni i stanów. Nim jednak przejdę do szczegółowej analizy, muszę dokładniej przybliżyć to, jak rozumiem polską gościnność, gdyż łatwo w tym względzie o nieporozumienia.

\section{MODELE GOŚCINNOŚCI}

Nie istnieje oczywiście jeden obowiązujący w całej Polsce wzorzec zachowań i jedno wyobrażenie gościnności. Mamy raczej do czynienia z mo- 
zaiką wariantów różniących się w sposób znaczący. Ich źródeł możemy szukać między innymi we względnie łatwych do wyodrębnienia porządkach stanowych: chłopskie praktyki przyjmowania gości różniły się od mieszczańskich, te zaś funkcjonowały inaczej niż szlacheckie. Na pewno należałoby także prowadzić badania w kierunku geograficznego zróżnicowania kształtu poszczególnych, lokalnie ukonstytuowanych formuł. Równie istotne byłoby historyczne dookreślenie najważniejszych etapów $\mathrm{w}$ transformacji wcześniejszych modeli i w konsekwencji dookreślenie źródeł dzisiejszych hybryd. Możemy też próbować odnajdywać niedawno ukonstytuowane dystynkcje społeczne i kulturowe, które rządzą formami gościnności kształtującymi się we współczesnych ośrodkach miejskich i wiejskich.

Praktyki gościnności ulegają bezustannym zmianom pod wpływem niezwykle różnorodnych czynników. Wymienić można chociażby te związane $z$ obowiązującymi normami wzajemności, sposobami kultywowania więzi społecznych, budowania poczucia przynależności i tożsamości, formami i znaczeniem współczesnych praktyk konsumpcyjnych czy zmianami obrzędowości dorocznej i tej towarzyszącej poszczególnym etapom życia. Niezwykle ważne dla przemian gościnności są także transformacje $\mathrm{w}$ sposobach organizowania się wspólnot i grup rodzinnych. Nie możemy również zapominać o kwestiach związanych $z$ napięciami i konfliktami charakterystycznymi dla sytuacji przyjmowania gości, wywoływanymi na przykład przez polaryzację polityczną czy gry statusowe.

W zależności od tych i wielu innych czynników różnie mogą być ustanawiane granice przestrzenne i czasowe gościny, inne mogą być jej cele, forma i rytm. Zmianom będą ulegały także chociażby taktyki służące wykorzystaniu gościny jako narzędzia realizacji konkretnych interesów. Można jednak zbudować - i to jest droga, którą chcę dalej podążać pewien ogólny, przydatny heurystycznie model. Zamaże on wprawdzie większość różnic charakterystycznych dla poszczególnych wariantów, ale pozwoli skupić się na aksjonormatywnej płaszczyźnie kultury, od której rzeczywistość często odbiega, ale która stanowi jeden z istotnych punktów odniesienia dla codziennych praktyk. Uzasadnieniem takiej strategii jest istnienie w kulturze polskiej automodelu gościnności będącego historycznie wynegocjowanym i obecnym w języku, abstrakcyjnym konstruktem semantycznym. Konstruktem, który przemieszcza się pomiędzy kontekstami, znakując różne aspekty rzeczywistości.

Zestawienie automodelu i konkretnych kulturowych realizacji pozwala wyodrębnić przynajmniej trzy konstytutywne wyróżniki aksjonormatyw- 
nego wzorca gościnności polskiej ${ }^{6}$. Pierwszym z nich jest "geocentryzm”, czyli wyobrażenie ładu społeczno-kulturowego jako kręgów przynależności i relacji oddalenia formujących się wokół stabilnego, autonomicznego centrum. Centrum tym może być przestrzennie lub funkcjonalnie wyemancypowana jednostka lub grupa, na przykład rodzina żyjąca w obrębie materialnych granic ustanawianych przez dom lub mieszkanie. Druga cecha łącząca się z opisywanym modelem to „zasada relacyjnej asymetrii” przyjmująca postać powszechnie obowiązującej diady gospodarz-gość, która zawiera dysproporcje władzy wynikające z różnicy między tym, kto posiada i przynależy, a tym, kto na danym terytorium jest pozbawiony wynikających $z$ tego tytułu praw (Pisarek 2016, s. 224) ${ }^{7}$. Ważne, że określenia takie jak „gospodarz" i „gość” nie mają tworzącej równowagę, przeciwnie centrowanej pary opisującej inne warianty relacji w trakcie gościny ani nie pozwalają na płynną zmianę perspektywy, w której centralna mogłaby stać się pozycja osoby, która przychodzi w odwiedziny (w języku to gospodarz zawsze jest w centrum). Dlatego właśnie wskazana wyżej asymetryczność stanowi ważny element szkieletu opisywanego tu automodelu.

Trzeci wyróżnik opisywanego wzorca łączy się ze „strukturalnym niedopasowaniem" wpisanym w każde gościnne spotkanie. Następuje ono zawsze wtedy, gdy bliskość czasoprzestrzenna wynikająca ze spędzania ze sobą czasu jest przełamywana dystynkcją budowaną na bazie różnic przynależnościowych (do różnych rodzin, grup towarzyskich, zawodowych, etnicznych) oraz stosunków własnościowych (gościem nie można być u siebie). To niedopasowanie jest konieczne, by gościnność mogła zaistnieć - jest bowiem w prezentowanym wzorcu formą nawiązywania i kultywowania zażyłych relacji mimo istniejących odrębności i dzięki nim (Stasch 2009, s. 16; Pisarek 2016, s. 237).

Takie strukturalne zależności występujące $\mathrm{w}$ wielu różnych konfiguracjach (zależnych chociażby od dominujących wzorców zamieszkiwania

${ }^{6}$ Wnioski te są sformułowane na podstawie badań opublikowanych w książce Gościnność polska. O kulturowych konkretyzacjach idei. Badania były prowadzone na ograniczonym terenie Górnego Śląska, ale interesowało mnie przede wszystkim napięcie między „historycznie wynegocjowanym modelem semantycznym obowiązującym na poziomie abstrakcji $\mathrm{w}$ całym kraju a splotem partykularnych uwarunkowań, które wpływały na gościnność w jej konkretnej, kulturowej realizacji” (Pisarek 2016, s. 11). Poszukiwałem więc rozmaitych iteracji zasad stojących za organizacją różnych form kulturowych, które umożliwiają poruszanie się abstrakcyjnej „gościnności” od konkretu do ogółu.

7 Ostatnio odkrywczo o gościnnych diadach w innych kulturach pisał Rupert Stasch (2009, s. 74-76), a jednym z prekursorów studiów nad diadycznymi strukturami w praktykach gościnności był Julian Pitt-Rivers (1968). 
czy charakteru grupy korporacyjnej ${ }^{8}$ ) stanowią o tych aspektach gościnności, które mogą sprzyjać tworzeniu żywych stref wyobraźni. To właśnie one powodują także, iż praktyki przyjmowania gości mogą stanowić przestrzeń oporu przed biurokratycznym porządkiem i skrajnymi, asymetrycznymi relacjami władzy opartymi na przemocy. Nie jest to jednak oczywiste przy tak ogólnie zarysowanym modelu. Dlatego w dalszej części rozważań przyjrzę się przede wszystkim tym aspektom wzorca aksjonormatywnego - występującym w różnorodnych wariantach i realizacjach — które mogą chronić intensywną pracę wyobraźni przed naporem zewnętrznych form kontroli i logiką rynku opartego na kategorii zysku.

Swoje wnioski opierać będę na analizie danych zgromadzonych w Archiwum Badań nad Życiem Codziennym ${ }^{9}$ oraz informacjach zdobytych w trakcie badań dotyczących problematyki gościnności na Górnym Śląsku (Pisarek 2016, s. 238). Ważnym źródłem wiedzy o współczesnych polskich praktykach przyjmowania gości jest dla mnie także książka Gość $w$ dom pod redakcją Bogumiły Matei-Jaworskiej oraz Marty Skowrońskiej (2019). Warto przy tym zaznaczyć, że problematyka gościnności w polskiej literaturze kulturoznawczej, antropologicznej i socjologicznej była obecna od dawna, ale też rozproszona i rzadko formułowa wprost (pojawia się często między innymi przy okazji omawiania problemów związanych z obrzędowością, stylami życia, formami zamieszkiwania, rolą jedzenia i problemem polityki migracyjnej oraz tolerancji). Będę więc korzystał także $z$ dotychczasowych ustaleń poczynionych podczas realizacji inaczej zarysowanych projektów badawczych, zwracając uwagę na te wątki, które pozwolą na dookreślenie istotnych - w kontekście ożywiania wyobraźni społecznej - cech rekonstruowanego tu wzorca.

\section{STREFA WYMIANY PERSPEKTYW}

U podstaw gościnności rozumianej jako wzorzec aksjonormatywny stoi — jak wspomniałem wyżej - fundamentalna asymetria wpisana w rolę gościa i gospodarza. Analizy lingwistyczne wskazują, że gościem się „bywa” oraz „staje” — w języku uwypukleniu uległa tymczasowość tej pozycji, temporalność statusu oraz jej aspekt transformacyjny (Kłosińska, Sobol, Stankiewicz 2005, s. 125). Bycie gos podarzem łączy się nato-

\footnotetext{
8 Grupa korporacyjna jest tu rozumiana, zgodnie z klasyczną definicją, jako „zespół osób podlegający kontynuacji w czasie niezależnie od indywidualnego życia członków, posiadający kolektywne dobra oraz umiejscowiony terytorialnie (Staszczak 1987, s. 149).

9 Dostępnych na stronie Archiwum w części „O gościach i w gościach. Oblicza gościnności — wywiady" (http://archiwum.edu.pl [dostęp: 22.09.2019]).
} 
miast z kategoriami własności i władzy nad określonym terytorium - to wchodzenie w buty „pana domu”, „właściciela czegoś”, „zarządcy” (Jadacka 2001, s. 570). Ważne jest także to, że większość profili pojęcia "gość" tworzona jest $z$ punktu widzenia podmiotu, jakim jest „gospodarz”. Gość okazuje się tym, kto przychodzi - pojawia się z zewnątrz i pozostaje obcym w miejscu postrzeganym jako centrum (Pisarek 2016, s. 45).

Taka konstrukcja widoczna na poziomie języka łączy się także ze względnie stabilnymi wzorcami ról społecznych oraz często precyzyjnie określonym zestawem obowiązków i oczekiwań. Przyjmowała ona oczywiście wiele różnorodnych, historycznych postaci podkreślających asymetryczność owej relacji, a związanych chociażby ze spotkaniami osób o różnych majątkach i pochodzeniu. Nie jest ona jednak niczym szczególnym i występującym wyłącznie w kulturze polskiej. Julian Pitt-Rivers (2012, s. 513-516) zdiagnozował, że diadę gospodarz-gość możemy uznać za występującą powszechnie wówczas, gdy przestrzeń i związane z nią instytucje są wartościowane jako swoje lub obce. Poczucie własności, przynależności, potrzeba sprawowania nadzoru i władzy, czy też komfort płynący z uzyskania autonomii, są czynnikami wpływającymi na konstytuowanie się praw, obowiązków, norm i wartości związanych z asymetrycznymi statusami nadawanymi osobom, które przybywają w odwiedziny, a tymi, które przyjmują ich u siebie.

Struktura taka umożliwia rozwój przynajmniej dwóch tendencji — hierarchizującej i demokratyzującej. Ta pierwsza może być wzmacniana na przykład przez demonstracyjne akty hojności, których jedna ze stron nie jest w stanie odwzajemnić. Inne modelowe rozwiązanie to budowanie systemu ekwiwalencji pozwalającego zrównoważyć ową asymetrię. Właśnie na nim chciałem się skupić, gdyż łączy się $z$ angażowaniem dwóch stron kontaktu $\mathrm{w}$ złożone procesy pracy interpretacyjnej. Innymi słowy - to właśnie dzięki niemu gościnność może sprzyjać powstawaniu żywych stref wyobraźni.

Przyjrzyjmy się więc kilku poziomom, na których ekwiwalencja świadczeń różnego typu ma służyć budowaniu (często kruchej) równowagi. Zacznijmy od praktyk związanych z próbami wczuwania się w trakcie gościny w drugą stronę kontaktu. Współczesne formy tych zachowań analizuje Bogumiła Mateja-Jaworska (2019), co pozwala jej wysunąć wniosek, że gościnność to ćwiczenie wyobraźni społecznej i refleksyjności. Zaznacza, że w badanych przez nią sytuacjach zarówno gospodarze, jak i goście musieli być skoncentrowani na sobie nawzajem - czytać werbalne i niewerbalne sygnały, by nie dopuścić do psujących atmosferę nieporozumień. Używali zrozumiałych dla dwóch stron konwencji, wymagane było, by sprawnie je 
dekodowali, wykonując pracę semiotyczną, pracę empatii i pracę emocjonalną. Bez niej gościnność w opisywanym modelu jest nie do wyobrażenia (Mateja-Jaworska 2019, s. 90). Maja Brzozowska-Brywczyńska (2019, s. 150) w swoich badaniach na temat gościnności również odnosi się do tej sfery negocjowania relacji w czasie gościny, uznając je za „terytorium intuicji, domysłów, wzajemnego czytania wysyłanych przez obydwie strony subtelnych sygnałów". Zawieszone w wysokim kontekście (Hall 1984, s. 146-158), niewysłowione reguły, zasady, wartości i potrzeby skłaniają wszystkich do ciągłej aktywności - ciągłego wchodzenia w skórę drugiego człowieka. W ten sposób wyobraźnia kwitnie.

Ewa Kosowska (2002, s. 92-98) w badaniach dotyczących polskiej kultury szlacheckiej wskazuje, że rozwinął się w jej obrębie wzorzec, w którym wartości niematerialne mogły służyć spłaszczaniu hierarchii w różnych formach gościny. Ten trop przynajmniej częściowo tłumaczy rozległy zakres współczesnej pracy interpretacyjnej. Szerokość spektrum tego, co podlega w trakcie gościny wymianie, powoduje bowiem, że hierarchiczność sytuacji może być przełamywana na wiele sposobów (niekoniecznie związanych z wartością dóbr materialnych). Życzliwość, dowcip czy szacunek ${ }^{10}$ okazują się istotnymi przedmiotami wymiany, które oferowane są w zamian za gościnne przyjęcie. Ekwiwalencja ustanowiona na tym poziomie pozwala na uznanie wzajemnej chęci odczytywania intencji, opinii i emocji drugiej strony za wartość mogącą być bazą wymiany szeroko rozumianych świadczeń spłaszczających hierarchie oparte na pochodzeniu czy majątku.

Oczywiście taka forma wymiany i intensywnej pracy interpretacyjnej nie jest w stanie całkowicie spłaszczyć owych relacji — władza nie jest bowiem $\mathrm{w}$ trakcie pojedynczego spotkania rozdysponowana równo; trwają także różnego rodzaju gry społeczne związane $z$ negocjowaniem statusu gości i gospodarzy lub na przykład eskalowaniem lub unikaniem konfliktu. Okazuje się jednak, że istnieje jeszcze inny aspekt wzorca, który należy wziąć pod uwagę. Zwraca na to uwagę Ariel Modrzyk (2019). Wykorzystując $w$ analizie Heglowski model Pana i Sługi, zauważa podwójność pozycji gościa i gospodarza. Badane przez niego praktyki gościnności łączą się przy tym z szeregiem przesunięć pozwalających na zmianę „punktu widzenia” i ról przyporządkowanych poszczególnym osobom uczestniczącym w spotkaniach. Przesunięcia te oparte są na normie mówiącej o konieczności odwzajemnienia wizyty, co staje się zachętą do przesunięcia centrum go-

10 O szacunku i honorze jako sile napędowej gościnności pisał w swoich etnograficznych studiach m.in. Michael Herzfeld (1987). 
ścinności z jednego domu do drugiego. Za tą zmianą idzie kolejna — gość staje się gospodarzem, gospodarz gościem.

Okazuje się więc, że opisywany wzorzec może łączyć się z przechodnimi kategoriami, a zmiany przestrzeni pozwalają wprawić je w ruch. O tego typu diadach pisali Alan Rumsey (1993) i Rupert Stasch (2009) - analizowali kulturowe użycia zaimków „ja” i „ty”, zwracając uwagę, że „poprzez naprzemienne przyjmowanie pozycji wpisanej w [owe] zaimki $[\ldots] \mathrm{w}$ trakcie rozmowy, dana osoba jest w stanie wyobrazić sobie, że inni ludzie doświadczają tych samych perspektyw" (Stasch 2009, s. 47). Gdy ktoś dąży do zachowania odrębności i podkreślania asymetryczności gościny, norma zachęcająca do zmiany miejsca spotkań może więc pełnić ważną rolę - wspiera budowanie poczucia tożsamości i równoważności dwóch pozycji. Gdy łączy się z odwróceniem ról, praw i obowiązków, pozwala także na spłaszczanie hierarchii w zgodzie z cyklami wizyt i rewizyt. Tym samym wspiera utrzymanie równowagi w zakresie pracy interpretacyjnej podejmowanej po każdej z dwóch stron kontaktu. Hierarchie się odwracają, co ma zagwarantować symetrię władzy w asymetrycznej formule spotkania. Spowolnienie rytmu lub zaburzenie cyklu staje się wtedy znakiem oddalenia. Jego utrzymanie natomiast wiąże się z wyobrażeniem equilibrum, a przyspieszenie oznacza zwykle transformację więzi w stronę większej zażyłości.

Omawiany wzorzec gościnności może być więc uznany za sprzyjający powstawaniu stref żywej wyobraźni ze względu na związek z określoną formą ekwiwalencji świadczeń i logiką wymiany, związaną z koniecznością okazania szacunku, budowania zgody i odwzajemnienia uprzejmości (a także wizyt).

\section{STREFA PRAKTYKOWANIA UTOPII}

Badania nad utopiami, dotyczące nie tylko konstruktów literackich czy filozoficznych, lecz przede wszystkim codziennych praktyk społecznych, zainicjowały namysł nad tym, w jaki sposób ludzie starają się tworzyć enklawy alternatywnych porządków organizacyjnych lub własne heterotopie (Foucault 2005, s. 120-121). Badacze tacy jak Ruth Levitas (1990, 2013), interesując się procesami tworzenia przekształconych przez lokalne społeczności mikroświatów, zwracają uwagę na koncepcje i przejawy działań, które mają na celu budowanie lepszych i oryginalnych sposobów funkcjonowania w społeczeństwie. Interesuje ich zarówno praca koncepcyjna, jak też ostateczne formy autorskich (indywidualnych lub zbiorowych) pomysłów na życie. 
Zwracając uwagę na te wątki, chciałem zaznaczyć, że gdy piszę o gościnności jako strefie praktykowania utopii, właśnie do takiego rozumienia tego pojęcia się odwołuję. Nie o wielkie, często narzucane przemocą wizje mi chodzi. Nie twierdzę również, że u podstaw opisywanego modelu gościnności stoi pewien przemyślany plan zakorzeniony w możliwym do zrekonstruowania obrazie doskonałego społeczeństwa. Interesuje mnie raczej to, czy praca wyobraźni (w tym praca interpretacyjna) ${ }^{11} \mathrm{~W}$ obszarze relacji społecznych wspiera się na konstruktach odwołujących się do utopijnych i wyidealizowanych założeń dotyczących człowieka i świata społecznego (lub je tworzy). Od razu odpowiem na to pytanie - jestem przekonany, że omawiany wzorzec ma wiele wspólnego $z$ wyobraźnią utopijną, która nie pozostaje jednak wyłącznie na poziomie deklaratywnym, ale wchodzi też $\mathrm{w}$ relacje $z$ konkretnymi praktykami, decyzjami, przekonaniami czy scenariuszami spotkań, często stanowiąc dla nich punkt odniesienia lub klucz interpretacyjny.

Pierwszy z utopijnych punktów oparcia znajduję w relacjach między wyobrażeniami o tym, czym powinna być gościnność, a chrześcijańską cnotą hospitalitas (Pytel 1990, s. 83; Cetwiński 2004, s. 37). Obowiązek opieki nad podróżującymi, pielgrzymami, ubogimi i chorymi wpisany jest $\mathrm{w}$ jądro nowotestamentowej etyki. Razem $\mathrm{z}$ agape $\mathrm{i}$ caritas stanowi klucz do zrozumienia charakterystycznego dla naszej kultury związku czci i zobowiązania do niesienia pomocy, należnych obcym przybyszom uznanym w danej sytuacji za gości. Hospitalitas łączące się z wyobrażeniami o działalności dobroczynnej odnajdujemy dzisiaj na poziomie myślenia o gościnności jako bezinteresownej pomocy drugiemu człowiekowi i akcie człowieczeństwa łączącego się z otwarciem na szeroko rozumianego Innego. Współczesny dyskurs tworzący się wokół kryzysu migracyjnego często korzysta $z$ takiego punktu odniesienia, a wartościowanie decyzji politycznych łączy się z przywoływaniem właśnie tak rozumianej gościnności (często niezależnie od strony sporu).

W oddolnych narracjach o codziennych praktykach ten kontekst również występuje niezwykle często. Należy go jednak traktować przede wszystkim jako abstrakcyjny wzorzec idealny, który tylko czasami bywa wdrażany w życie w zwyczajowych praktykach gościnności. Stanowi raczej

${ }^{11}$ Graeber przywołuje w tym kontekście Marksa, pokazując, że ten za wyjątkową, wyróżniająca cechę człowieka uznawał zdolność do wznoszenia gmachów najpierw w wyobraźni właśnie, a dopiero później w rzeczywistości. Jednocześnie zaznacza, że Marks nie dysponował teorią pozwalającą mu wytłumaczyć, dlaczego wyobraźnia działa inaczej w sferze produkcji materialnej, a inaczej w toku ustanawiania i utrwalania więzi. Mnie interesuje tu wyłącznie drugi obszar wspomniany przez Graebera (2016, s. 120-121). 
ważną część narracji o tym, co oznacza być gościnnym, dobrym człowiekiem (Pisarek 2016, s. 105-111). Biurokratyzacja pomocy jako szeregu świadczeń i działań związanych $z$ instytucjami państwa, Kościoła i trzeciego sektora spowodowała bowiem, że stojące za ową pomocą wartości przestały łączyć się bezpośrednio z praktykami przyjmowania gości $\mathrm{w}$ domu. Znajdują raczej wyraz w życiu zawodowym lub wolontariacie osób zaangażowanych w tę sferę działalności publicznej.

Druga płaszczyzna utopijnej gościnności łączy się z narracjami o znaczeniu więzi międzyludzkiej. To skojarzenie może wydawać się kontrowersyjne i nie wystarczą deklaratywne wypisy z badań terenowych czy pamiętników, w których pojawiają się formuły takie jak: „Najważniejszy jest drugi człowiek" (Mateja-Jaworska 2019, s. 76). Nie wystarczą też badania wskazujące, że w tekstach kultury polskiej więzi społeczne od dawna stanowiły sferę najbardziej cenioną (Kosowska 1985). Zauważmy, że gościnność okazuje się w kulturze polskiej nie tylko „normą średniego zasięgu" (Modrzyk 2019, s. 164), ale przede wszystkim wartością autoteliczną, co do jej istoty nikt się nie spiera ${ }^{12}$. Dopiero jako taka abstrakcja, a także wartość podkreślająca rolę wspólnoty, stała się punktem wyjścia do powstawania różnych norm społecznych, wręcz wytyczną stanowiącą czynnik wpływający na charakter konkretnych decyzji dotyczących utrzymywania lub zrywania relacji społecznych.

Jej aspekt najbardziej prozaiczny, ale niezwykle ważny dla dynamiki wyobraźni widoczny staje się dzięki analizom norm gościnnych spotkań. Niepisaną zasadą (nie zawsze realizowaną) jest to, by unikać kłótni, trudnych tematów i dążyć do porozumienia ponad podziałami, chociażby na czas trwania spotkania. W trakcie wielu gościn wykonywana jest olbrzymia praca, by tworzyć wspólny grunt i porozumienie, a wykluczać to, co buduje różnice i granice. Łatwa do zrekonstruowania lista tematów polecanych i niewskazanych stanowi dobry przykład ukierunkowywania wyobraźni pod kątem wspólnych wartości (Mateja-Jaworska 2019, s. 83-93). Równie istotne w tym kontekście są wszystkie zakazy, które potrafią uczynić z gościny sytuację wręcz opresyjną, a na pewno niekomfortową (Krajewski 2019, s. 41, 48). Pomagają one jednak w utrzymaniu kruchej równowagi w sytuacji asymetrycznej relacji władzy i świadczą o wartości nadrzędnej, która łączy się z utopijnym wyobrażeniem wspólnoty.

Praktyki gościnności mogą dzięki temu stać się formą ćwiczeń z empatii wynikających $z$ umocowanej kulturowo potrzeby wczucia się $\mathrm{w}$ drugą

12 Co najwyżej problem może wywoływać pytanie, wobec kogo należy pozostawać gościnnym. Tu pojawią się i wyraźne granice, i znaczny poziom wykluczenia. 
stronę spotkania, a także sposobem na wytwarzanie wspólnego gruntu — obiektywizacji fundamentów świata, co pozwala na zbudowanie większej zażyłości (lub przynajmniej na powstrzymanie wrogości). Bogumiła Mateja-Jaworska odkrywa te procesy w rozmowach o pogodzie, sporcie, wieściach z miasta, wspomnieniach, żartach. Jest to tworzenie „klejów społecznych” oraz „budowanie poczucia intersubiektywnej rzeczywistości" (Mateja-Jaworska 2019, s. 84) lub — jak pisał Michael Herzfeld (2007, s. 39) - działanie zmierzające do „reifikacji oraz esencjalizacji” porządku społecznego.

Równowagę sytuacji gościny pozwala utrzymać także zasada wykluczenia ze strefy gościnności rozumianej jako wartość wszystkich transakcji opartych na kategorii zysku i związany z tym opór przed utowarowieniem relacji i osób. Prezenty i podarunki przekazywane przy okazji różnorodnych wizyt są tego doskonałym świadectwem. Jako dary wymagają odwzajemnienia, ale na poziomie norm nie powinny być zastępowane przez świadczenia pieniężne (choć oczywiście bywają - ale wtedy pieniądz pełni rolę daru, dar nie staje się pieniądzem). W kontekście opisywanego modelu w mocy pozostaje ogólna teza Maurice'a Godeliera: prezent w systemach kapitalistycznych jest kojarzony przede wszystkim ze sferą bezinteresownych, zażyłych stosunków (pokrewieństwa, przyjaźni itp.): „Poświadcza zażyłość brakiem wyrachowania, odmową traktowania ludzi nam bliskich jako środka służącego osiągnięciu własnych celów" (Godelier 2010, s. 252). Podarunek staje się azylem wyobrażeń o solidarności i hojności dawnych epok, a więc kolejnym, tym razem materialnym, nośnikiem pewnej utopii. David Graeber w swojej krytyce późnokapitalistycznych społeczeństw sprawnie łączy ten wątek $z$ kwestią więzi społecznych:

„Opiekę, energię i pracę poświęconą innym ludziom powinno się traktować jako fundamentalną. Wszystko, na czym nam najbardziej zależy — nasze miłości, pasje, rywalizacje i obsesje — to zawsze inni ludzie. W większości społeczeństw niekapitalistycznych jest czymś oczywistym, że wytwarzanie dóbr materialnych jest podrzędnym składnikiem większego procesu, jakim jest kształtowanie ludzi. Kapitalizm zmusza nas, abyśmy udawali, że jest odwrotnie: że społeczeństwo istnieje po to, byśmy produkowali coraz więcej dóbr materialnych" (Graeber 2016, s. 123-124).

Przyjmowanie gości i przekazywanie prezentów w tej wykładni stanowiłoby czasowe przywracanie i podkreślanie wagi dawnego porządku, nastawionego na więź i człowieka. Nie da się jednak bez pewnej podejrzliwości przyglądać opowieściom takim jak ta snuta przez Graebera. Stanowią one bowiem formy podobne do polskich, nostalgicznych narracji o przeszłości - czasach, gdy gościnność była wielka i bezinteresowna, 
a każdy mógł znaleźć schronienie i pomoc w potrzebie. Tak semiotyzowane $\mathrm{w}$ Polsce są Kresy oraz polska wieś - pozostają gościnnymi przestrzeniami, bezpośrednio łącząc się z utopijnym wyobrażeniem, w którym altruistyczne relacje międzyludzkie były nie elementem, lecz fundamentem życia społecznego. To wyobrażenie o byciu nieskończenie gościnnym stało się także narzędziem konstruowania i umacniania polskiej tożsamości narodowej.

Paradoksalnie więc praca interpretacyjna i rozkwit wyobraźni społecznej są możliwe po części dlatego, że gościnność uznawana jest za autoteliczną całość, nawet jeśli taka całość nie istniała nigdy inaczej niż jako utopia. Swoją siłę bierze ona bowiem z wzorców idealnych i nostalgicznych narracji, które stanowią autonomiczny obszar chroniony przed wpływami innych płaszczyzn systemu kulturowego. Między innymi dlatego może stawać się dyskursywnym narzędziem pozwalającym stawiać opór procedurom i przemocy biurokratycznej maszynerii. W tym kontekście gościnność może być interpretowana jako forma miękkiego sprzeci$\mathrm{wu}$, ale często $\mathrm{w}$ zderzeniu $\mathrm{z}$ codziennością i $\mathrm{w}$ odniesieniu do innych cenionych przez jednostki wartości bywa kojarzona z odtwarzaniem skostniałych konwencji. Dlatego tradycyjna gościnność zyskała także dyskursywne drugie oblicze - związane z podkreślaniem restrykcji, przymusu spotkania, konieczności ujarzmiania własnej indywidualności oraz funkcjonowania sytuacji kontroli (Krajewski 2019, s. 49; Skowrońska 2019, s. 99-111).

\section{STREFA GRY}

Praktyki przyjmowania gości jawią się jako pełne napięć. Dotychczas pisałem o owych napięciach pobieżnie, zwracając uwagę raczej na to, co $\mathrm{w}$ przywoływanym modelu związane jest $\mathrm{z}$ jego trwałością. Ale przecież każda sytuacja gościny tworzy wyjątkową dynamikę, która opiera się na konfrontacji stabilnych struktur określających podstawowe warunki działania i dających bazowe wytyczne dla gościnnych osób z taktykami wykorzystywanymi, żeby w obrębie owych struktur się poruszać.

Różne warianty konwencji przyjmowania gości i wzorca aksjonormatywnego, który służy jej stabilizacji, wiążą się ze zmiennym poziomem kontroli zachowań i gradacją możliwości stosowania idiosynkratycznych, improwizowanych scenariuszy. Na przykład tradycyjna mongolska gościnność jest związana $z$ technikami minimalizowania spontaniczności i opiera się na zestawie łączących się z semiotyzacją przestrzeni i dyscyplinowaniem ciał norm, których należy przestrzegać (Humphrey 2012, s. 71). 
W obrębie polskich wariantów gościnności stopień konwencjonalizacji zachowań może być bardzo różny. Ważniejsze okazje do spotkań — związane między innymi z wydarzeniami cyklu życiowego i rocznego - zwykle są bardziej restrykcyjne, jeśli idzie o normy, te bliskie codzienności często mogą być bardziej spontaniczne. Zauważana w wielu badaniach sztuczność sytuacji, jej konwencjonalność, a jednocześnie pozytywne wartościowanie spontaniczności (Brzozowska-Brywczyńska 2019, s. 131) znajduje wyraz w strukturze czasowej gościnnych wizyt. Często przyjmują one bowiem formę, w której początkowe konwenanse ulegają rozluźnieniu, a dramaturgia gościny jest związana z powszechnie akceptowanym szczęśliwym zakończeniem - zwycięstwem spontaniczności nad konwencją. W takim przypadku proces i zabiegi wytyczające kierunek transformacji (z relacji usztywnionych obowiązującymi i przestrzeganymi normami w zażyłość, której konwencja gościny daje przestrzeń) okazują się kolejnymi sposobami pozwalającymi na osiągnięcie symetryczności relacji i rozkwit pracy wyobraźni wymykającej się hierarchicznym układom. Wydaje się, że owe zabiegi są związane, przynajmniej po części, z charakterem omawianego wzorca aksjonormatywnego.

Każda z opisanych wyżej sytuacji jest narażona na porażkę. Nie wszystkie gościny kończą się przecież wspólną zabawą wszystkich ze wszystkimi. Napięcia, stres i samokontrola niekoniecznie znikają. Wydaje się, że może to być wynik nadrzędności ról gospodarza i gościa, które mają ograniczać możliwość porażki w grze zażyłości i pozwalać na niekonfliktowe wycofanie się każdej ze stron. Przede wszystkim jednak umożliwiają transformację i budowanie bliższych więzi bez konieczności rozbicia dotychczasowych sposobów organizacji grupy - gospodarz nie martwi się przecież zwykle tym, że gość zostanie nowym domownikiem i lokatorem. Diada gospodarz-gość jest więc zestawem pozycji służących mediowaniu między różnymi płaszczyznami ładu społeczno-kulturowego i daje gwarancję jego utrzymania.

Niemożliwa przy tym wydaje się całkowita eliminacja napięć powstających przy okazji przyjmowania gości - większość z nich wynika bowiem $z$ cech konstytutywnych dla tego typu sytuacji, które są przecież formą naruszania pewnych granic utrzymujących ważne porządki przynależnościowe. Nic więc dziwnego, że różne formy gościnności muszą mieć swoje ograniczenia - są bowiem swoistymi regulatorami pozwalającymi na uczynienie z nieprzekraczalnych barier przenikalnych błon. Nic też dziwnego, że wzorzec aksjonormatywny odległy jest od rzeczywistych praktyk i blisko mu do sfery utopi, co powoduje, że trudno w nim dostrzec takie aspekty gościnności, jak wyraziste tabuizacje ekspansywnych zachowań 
i sprawowanie normatywnej kontroli nad newralgicznymi aspektami spotkania ${ }^{13}$.

Ten sam wzorzec daje jednocześnie szansę na kształtowanie się trwałych, stanowiących element kultury żywych stref wyobraźni. Gościnne spotkanie może stać się areną ustabilizowanej gry wyobraźni i obietnicą podtrzymania zażyłości w obrębie struktur rodzinnych i towarzyskich. Kosztem takiego sprofilowania gościnności jest zapewne brak w tym wzorcu otwartości na Innego. Brak też przestrzeni pracy interpretacyjnej skierowanej na zewnątrz ukonstytuowanych struktur. Można z takiej diagnozy wyciągnąć ważny wniosek - ustanowienie i utrzymanie żywej strefy wyobraźni może wiązać się z równoczesnym powstawaniem martwoty tuż obok. Gdy w jednym miejscu praca interpretacyjna kwitnie, w drugim zanika.

\section{PODSUMOWANIE: DWA OBLICZA WYSPY}

Wyobraźnia, o której pisze Graeber, ma na celu zbudowanie nowych form wspólnotowości. Pozwala na rekonfigurację dotychczasowego porządku w momentach rewolucyjnych. Często jej rozkwit, mimo że krótkotrwały, pozwala stworzyć fundamenty alternatywnych światów. Opisywany wzorzec gościnności nie ma natomiast tak dużego potencjału wywrotowego, transformacyjnego i inkluzyjnego. Może stać się punktem odniesienia i inspiracją do odgrywania kameralnych, odbywających się w małych grupach form utrwalania i powtarzania podstawowych zasad i wartości tworzących wyobrażenie ładu społeczno-kulturowego. Pomaga w negocjowaniu porozumień i wzmacnianiu więzi opartych na pracy interpretacyjnej przekraczającej asymetryczne relacje władzy.

W drugiej połowie XX wieku tradycyjna gościnność, zwłaszcza ta związana $z$ obszarami wiejskimi, zaczęła zmieniać się $\mathrm{w}$ narzędzie służące przede wszystkim umożliwieniu bezkonfliktowego funkcjonowania jednostek w ramach coraz bardziej różnicujących się porządków przynależnościowych (rodzina, praca, znajomi). Stała się także nośnikiem utopi, która pozwala zachować trwałość tych relacji w ich coraz większym rozproszeniu oraz jednocześnie ocalić spoistość gospodarstwa domowego. Mniej w niej pozostało $z$ mechanizmu pozwalającego radzić sobie z przybyszami spoza znanej wspólnoty. Paradoksalnie, możliwe, że właśnie dzięki temu procesowi była wciąż obok, a czasami wręcz w znaczącej kontrze do

13 Ograniczenia gościnności i związanie z nimi aporie w swoich dekonstrukcyjnych studiach przeanalizował dokładnie Jacques Derrida (2004). 
biurokratycznego, wyzutego ze znaczeń porządku. Możliwe nawet, że dlatego dyskursywnie rozkwita jak nigdy wcześniej, choć z tego też powodu przestaje mieć włączający charakter i staje się przedmiotem współczesnej, krytycznej refleksji. Ujawniają się bowiem z wielką siłą głęboko wpisane w każdą sytuację gościny aporie - bycie gościnnym i otwartym wymaga zawsze ustanowienia granic, bez których gościnność nie byłaby możliwa. Widoczne staje się także to, że wzorzec aksjonormatywny, który często daje punkt odniesienia dla wartościowania konkretnych zachowań, często wydaje się oderwany od rzeczywistości.

Jednak właśnie ów wzorzec, stanowiąc czasami punkt odniesienia dla praktyk kulturowych, norm i narracji, daje warunki bazowe umożliwiające tworzenie specyficznych wysp - żywych stref wyobraźni. Zawiera wytyczne pozwalające na otwarcie owych wysp na nowe osoby. Jak to jednak bywa z wyspami - trudno do nich dopłynaćc. Gościnność nie jest przy tym traktowana jako czas na eksperymenty i szukanie nowych sensów, ale raczej jako formuła ustalania wspólnego minimum. Zwrócenie się ku temu wzorcowi pozwala także na wyobrażenie sobie przestrzeni gęstych od znaczeń, w których praca interpretacyjna każdego uczestnika jest intensywna i służy budowaniu porozumienia, uzgadniania znaczeń i wartości.

Gościnność rozumiana jako wartość może więc wpływać na kształtowanie się żywych stref wyobraźni w trakcie gościnnych spotkań. Może też wskazywać kierunek, który przybliży wybrane praktyki przyjmowania gości do praktyk oporu. Jednak tak jak według Victora Turnera każda communitas musi ostatecznie zamienić się $\mathrm{w}$ strukturę, tak też opisywany tu wzorzec może łączyć się z procesem o dwóch wektorach - interpretacyjnym i reifikacyjnym. Praca reifikacji pozwala wyłonić autonomiczną, opartą na konsensusie przestrzeń rozpiętą pomiędzy codziennością, wyobrażeniem ładu a utopią. Praca interpretacyjna natomiast służyć może temu, by poradzić sobie $z$ wpisanymi w każdą utopię i każdy ład aporiami. Ta złożona dialektyka bezpośrednio związana z gościnnością pozwala na tworzenie stref oporu w miejscach, w których biurokratyczny i neoliberalny porządek zaczyna oddziaływać $z$ dotychczas niespotykaną siłą. Ta sama dialektyka stoi jednak za powstawaniem ostrych granic sprawiających, że przestrzeń gościny nie jest dostępna dla wszystkich.

\section{BIBLIOGRAFIA}

Brzozowska-Brywczyńska Maja, 2019, Akrobatyczny wymiar gościnności albo kilka uwag o tańcu na linie gościa z gospodarzem, w: Bogumiła Mateja-Jaworska, Marta Skowrońska (red.), Gość $w$ dom. Wspótczesne praktyki przyjmowania gości, Wydawnictwo Naukowe UAM, Poznań. 
Cetwiński Marek, 2004, Opieka nad biednymi i jej rola w sprawowaniu władzy, w: Antoni Barciak (red.), Curatores pauperum. Źródła i tradycje kultury charytatywnej Europy Środkowej, Instytut Górnośląski, Katowice.

Derrida Jacques, 2004, Gościnność nieskończona, tłum. Paweł Mościcki, „Przegląd Filozoficzno-Literacki”, nr 3, s. 257-261.

Foucault Michel, 1977, Archeologia wiedzy, tłum. Andrzej Siemek, Państwowy Instytut Wydawniczy, Warszawa.

Foucault Michel, 1993, Nadzorować i karać. Narodziny więzienia, tłum. Tadeusz Komendant, Aletheia, Warszawa.

Foucault Michel, 2005, Inne przestrzenie, tłum. Agnieszka Rejniak-Majewska, „Teksty Drugie”, nr 6, s. 117-125.

Foucault Michel, 2010, Bezpieczeństwo, terytorium, populacja, tłum. Michał Herer, Wydawnictwo Naukowe PWN, Warszawa.

Geertz Clifford, 2005, Interpretacja kultur. Wybrane eseje, tłum. Maria M. Piechaczek, Wydawnictwo Uniwersytetu Jagiellońskiego, Kraków.

Godelier Maurice, 2010, Zagadka daru, tłum. Marta Höffner, Wydawnictwo Uniwersytetu Jagiellońskiego, Kraków.

Graeber David, 2002, The New Anarchists, „New Left Review”, nr 13, s. 61-73.

Graeber David, 2012, Dead Zones of the Imagination: On Violence, Bureaucracy, and Interpretive Labor, „HAU. Journal of Ethnographic Theory”, t. 2(2), s. 105-128.

Graeber David, 2016, Martwe strefy wyobraźni, w: David Graeber, Utopia regulaminów. O technologii, tępocie i ukrytych rozkoszach biurokracji, tłum. Marek Jedliński, Wydawnictwo Krytyki Politycznej, Warszawa.

Hall Edward, 1984, Poza kulturą, tłum. Elżbieta Goździak, Państwowe Wydawnictwo Naukowe, Warszawa.

Herzfeld Michael, 1987, "As in Your Own House": Hospitality, Ethnography, and the Stereotype of Mediterranean Society, w: David G. Gilmore (red.), Honor and Shame and the Unity of the Mediterranean, American Anthropological Association, Washington, D.C.

Herzfeld Michael, 2007, Zażyłość kulturowa. Poetyka społeczna w państwie narodowym, tłum. Michał Buchowski, Wydawnictwo Uniwersytetu Jagiellońskiego, Kraków.

hooks bell, 1992, Black Looks: Race and Representation, South End Press, Boston.

Humphrey Caroline, 2012, Hospitality and Tone: Holding Patterns for Strangeness in Rural Mongolia, "Journal of the Royal Anthropological Institute”, t. 18, s. 63-75.

Jadacka Hanna, 2001, Słownik gniazd słowotwórczych wspótczesnego języka ogólnopolskiego, t. 2, Universitas, Kraków.

Kłosińska Anna, Sobol Elżbieta, Stankiewicz Anna (oprac.), 2005, Wielki słownikfrazeologiczny PWN z przystowiami, Wydawnictwo Naukowe PWN, Warszawa.

Kosowska Ewa, 1985, Legenda. Kanon i transformacje. Św. Jerzy w polskiej kulturze ludowej, Ossolineum, Wrocław.

Kosowska Ewa, 2002, Negocjacje i kompromisy. Antropologia polskości Henryka Sienkiewicza, Wydawnictwo Naukowe Śląsk, Katowice.

Krajewski Marek, 2019, Stót, w: Bogumiła Mateja-Jaworska, Marta Skowrońska (red.), Gość $w$ dom. Wspótczesne praktyki przyjmowania gości, Wydawnictwo Naukowe UAM, Poznań.

Levitas Ruth, 1990, The Concept of Utopia, Peter Lang, Oxford. 
Levitas Ruth, 2013, Utopia as Method: The Imaginary Reconstitution of Society, Palgrave Macmillan, Basingstoke.

Mateja-Jaworska Bogumiła, Skowrońska Marta (red.), 2019, Gość w dom. Wspótczesne praktyki przyjmowania gości, Wydawnictwo Naukowe UAM, Poznań.

Mateja-Jaworska Bogumiła, 2019, Gościnne Polaków rozmowy, w: Bogumiła Mateja-Jaworska, Marta Skowrońska (red.), Gość w dom. Wspótczesne praktyki przyjmowania gości, Wydawnictwo Naukowe UAM, Poznań.

Mauss Marcel, 2007, Szkic o darze, w: Ewa Nowicka, Małgorzata Głowacka-Grajper (red.), Świat człowieka - świat kultury. Antologia tekstów klasycznej antropologii, Wydawnictwo Naukowe PWN, Warszawa.

Modrzyk Ariel, 2019, Utracona gościnność? Reguła tradycyjnej gościnności jako norma średniego zasięgu, w: Bogumiła Mateja-Jaworska, Marta Skowrońska (red.), Gość w dom. Współczesne praktyki przyjmowania gości, Wydawnictwo Naukowe UAM, Poznań.

Pisarek Adam, 2016, Gościnność polska. O kulturowych konkretyzacjach idei, grupakulturalna.pl, Katowice.

Pitt-Rivers Julian, 1968, The Stranger, the Guest, and the Hostile Host: Introduction to the Study of the Laws of Hospitality, w: John G. Peristiany (red.), Contributions to Mediterranean Sociology, Mouton, Paris.

Pitt-Rivers Julian, 2012, The Law of Hospitality, „HAU: Journal of Ethnographic Theory”, t. 2, nr 1, s. 501-517.

Pytel Jan Kanty, 1990, Gościnność w Biblii (studium źródłowo-porównawcze), Księgarnia Świętego Wojciecha, Poznań.

Skowrońska Marta, 2019, Czuj sie jak u siebie, ale bez przesady. Kontrola przestrzeni $i$ opieka nad gościem — dwa wymiary asymetrii władzy w sytuacji gościny, w: Bogumiła Mateja-Jaworska, Marta Skowrońska (red.), Gość w dom. Wspótczesne praktyki przyjmowania gości, Wydawnictwo Naukowe UAM, Poznań.

Stasch Rupert, 2009, Society of Others: Kinship and Mourning in a West Papuan Place, University of California Press, Berkeley.

Tomasello Michael, 2015, Historia naturalna ludzkiego myślenia, tłum. Bartłomiej Kucharzyk, Rafał Ociepa, Copernicus Center Press, Warszawa.

Turner Victor, 2005, Gry społeczne, pola i metafory. Symboliczne działanie w społeczeństwie, tłum. Wojciech Usakiewicz, Wydawnictwo Uniwersytetu Jagiellońskiego, Kraków.

Turner Victor, 2010, Proces rytualny. Struktura i antystruktura, tłum. Ewa Dżurak, Państwowy Instytut Wydawniczy, Warszawa.

\title{
LIVING ZONES OF THE IMAGINATION: RECEIVING GUESTS AS A PRACTICE OF RESISTANCE
}

\author{
Adam Pisarek \\ (University of Silesia in Katowice)
}

Abstract

This article concerns "living zones of the imagination"-areas of social life in which intensive "interpretive labor" is underway. Thanks to these zones, it is 
possible to engage in universally accepted exercises that enable a person to "see the world through the eyes of another person" and that yet do not disturb the current socio-cultural order. They provide an important basis for understanding among people, for harmonizing meanings in the sphere of social realities, and for integration that goes beyond certain permanent boundaries and hierarchies. The basic aim of the article is to prove that hospitality, understood as a value in Polish culture, could contribute to a considerable degree to the creation of such zones. The author analyzes the zones' character, function, and meaning, paying attention to how they resist the expansion of bureaucratic ways of organizing social life. He also draws attention to the influence that an axio-normative pattern could have within specific models of behavior and cultural practices.

Key words: hospitality, resistance practices, social imagination, interpretive labor

Stowa kluczowe: gościnność, praktyki oporu, wyobraźnia społeczna, praca interpretacyjna 